\title{
The Effects of Physical Activity and Obesity on Hypertension in Adolescents: Meta-Analysis
}

\author{
Maria Imakulata Berek1), Agus Kristiyanto²), Vitri Widyaningsih'3)
}

\author{
${ }^{1)}$ Masters Program in Public Health, Universitas Sebelas Maret \\ ${ }^{2}$ Study Program of Physical, Health, and Recreation Education, Universitas Sebelas Maret \\ 3)Faculty of Medicine, Universitas Sebelas Maret
}

\section{ABSTRACT}

Background: The incidence of hypertension is always increasing every year both in Indonesia and in the world. Adolescents with high blood pressure are more likely to become adults with hypertension if not treated immediately. This study aimed to review the effects of physical activity and obesity on hypertension in adolescents using meta-analysis.

Subjects and Method: Meta-analysis was performed by searching for articles from the database, namely Pubmed, Science Direct, Springer Link and Google Scholar. The keywords used are "physical activity" AND "obesity" AND "hypertension" OR "high blood pressure" AND "adolescent" AND "cross sectional". The inclusion criteria in this study were fulltext articles with a cross-sectional design, in English, for the period of 2010-2020. Article analysis was using RevMan 5.3.

Results: The total number of articles analyzed was 14 articles from Nigeria, Brazil, Gabon, Germany, Tunisia, Algeria, China, Egypt, Indo- nesia, Lithuania, Greece, and Ghana. The results of the meta-analysis showed that physical activity increased the incidence of hypertension in adolescents $(\mathrm{aOR}=2.70 ; 95 \% \mathrm{CI}=$ 1.81 to $\left.4.04 ; \mathrm{p}<0.001 ; \mathrm{I}^{2}=87 \%\right)$. Obesity increased the incidence of hypertension in adolescents $(\mathrm{aOR}=1.71$; CI 95\% $=1.34-2.17$; $<$ 0.001; $\left.\mathrm{I}^{2}=41 \%\right)$.

Conclusion: Physical activity affects the incidence of hypertension in adolescents. Obesity affects the incidence of hypertension in adolescents.

Keywords: hypertension, physical activity, obesity, adolescents

\section{Correspondence:}

Maria Imakulata Berek, Masters Program in Public Health, Universitas Sebelas Maret, Jl. Ir. Sutami 36A, Surakarta 57126, Central Java. Email: imma123433@gmail.com. Mobile: 085311622368.

\section{Cite this as:}

Berek MI, Kristiyanto A, Widyaningsih V (2020). The Effects of Physical Activity and Obesity on Hypertension in Adolescents: Meta-Analysis. J Health Promote Behav. 05(04): 296-305. https://doi.org/10.26911/thejhpb.2020.05.04.07.

cC (i) (-) Journal of Health Promotion and Behavioris licensed under a Creative Commons Attribution-NonCommercial-ShareAlike 4.0 International License.

\section{BACKGROUND}

Hypertension, known as high blood pressure, is a global public health problem that contributes to an increasing burden of disease including heart disease, stroke, kidney failure, death and disability (WHO, 2013).

The World Health Organization (WHO) states that hypertension is more common in low and middle income countries, namely 40\%, while developed countries are $35 \%$. Africa is the region with the most hypertension sufferers, which was 46\%, America 35\% and Southeast Asia 36\%. WHO also predicts that by 2025 about $29 \%$ of people in the world will experience hypertension(WHO, 2013).

Based on the results of Basic Health Research, the prevalence rate of hypertension in people aged $>18$ years old in Indonesia has always increased, starting from 
2007 at $31.7 \%, 2013$ at $25.8 \%$ and in 2018 it increased significantly by $34,1 \%$ (Ministry of Health RI, 2019).

The problem of hypertension in adolescents is an important concern because of the large number of adolescents in Indonesia and in the world. According to WHO, the world's adolescents population is 1.2 billion or $18 \%$ of the world's population. In Indonesia, based on the 2010 population census, the number of adolescents is 43.5 million or $18 \%$ of the Indonesian population (Data and Information Center of Ministry of Health RI, 2017).

The population projection results show that the number of adolescent age population in Indonesia will continue to increase until 2030 (Demographic Institute of FEB UI, 2017). Based on the results of the study, the prevalence of adolescents aged 11-17 years old suffering from hypertension was $3.2 \%$ and the prevalence of prehypertension was $15.7 \%$ (Falkner, 2010).

Blood pressure will increase with age and body size, which ranges from 13 to 18 years old. Adolescents with high blood pressure are more likely to become adults with hypertension if not treated immediately (Aglony et al., 2009).

One of the factors that led to an increase in the prevalence of hypertension among adolescents was the lack of physical activity carried out by adolescents. Nowadays, adolescents more often spend their time playing gadgets, watching TV and tutoring so that they take longer to sit and be driven or picked up by private or public vehicles rather than choosing to walk or bike (Batara et al., 2016).

Physical activity has been shown to have an effect on blood pressure. Research conducted by Amra et al. (2020) states that individuals with insufficient physical activity are 2.86 times more likely to suffer from hypertension than individuals with sufficient physical activity.

Hypertension is also a comorbidity that is most often found in adolescents with overweight (obesity) (Kelly et al., 2015). The increasing prevalence of obesity is also followed by an increase in the prevalence of comorbidities, including an increase in blood pressure (Indonesian Pediatric Association, 2014).

There is a strong relationship between hypertension and obesity in adolescents, indicating that the prevalence of hypertension in adolescents will increase (Flynn \& Falkner, 2011). Research by Arum (2019) states that obese adolescents were 2.51 times more likely to develop hypertension than adolescents with normal weight.

Yusrizal et al. (2016) and Amra et al. (2020) stated that obese individuals have a 2.44 times greater risk of suffering from hyperemia compared to those who are not obese.

Based on the results of various primary studies that show the influence between physical activity and obesity on the incidence of adolescent hypertension, it encourages researchers to conduct systematic review and meta-analysis study to combine and analyze several study results that have been carried out then draw conclusions about the effect of physical activity and obesity on the incidence of hypertension among adolescents.

\section{SUBJECTS AND METHOD}

\section{Study Design}

This study used meta-analysis and systematic review, the articles analyzed were searched in the pubMed, Google Scholar, Science Direct and Springer Link databases.

\section{Inclusion Criteria}

The inclusion criteria in this study were full text articles with cross-sectional study 
Berek et al./ The Effects of Physical Activity and Obesity on Hypertension in Adolescents

design, articles were in English, articles with multivariate analysis.

\section{Exclusion Criteria}

The exclusion criteria in this study were published articles and meta-analysis articles.

\section{Operational Definition}

Physical activity: movement activities that require or expend energy or planned body movements that involve repetitive body movements with the aim of increasing energy.

Obesity: accumulation of fat in the body that exceeds the need for normal body function by measuring Body Mass Index $\geq$ 95th percentile.

Hypertension: a condition characterized by increased blood pressure in adolescents $\geq 95^{\text {th }}$ percentile.

\section{Data Analysis}

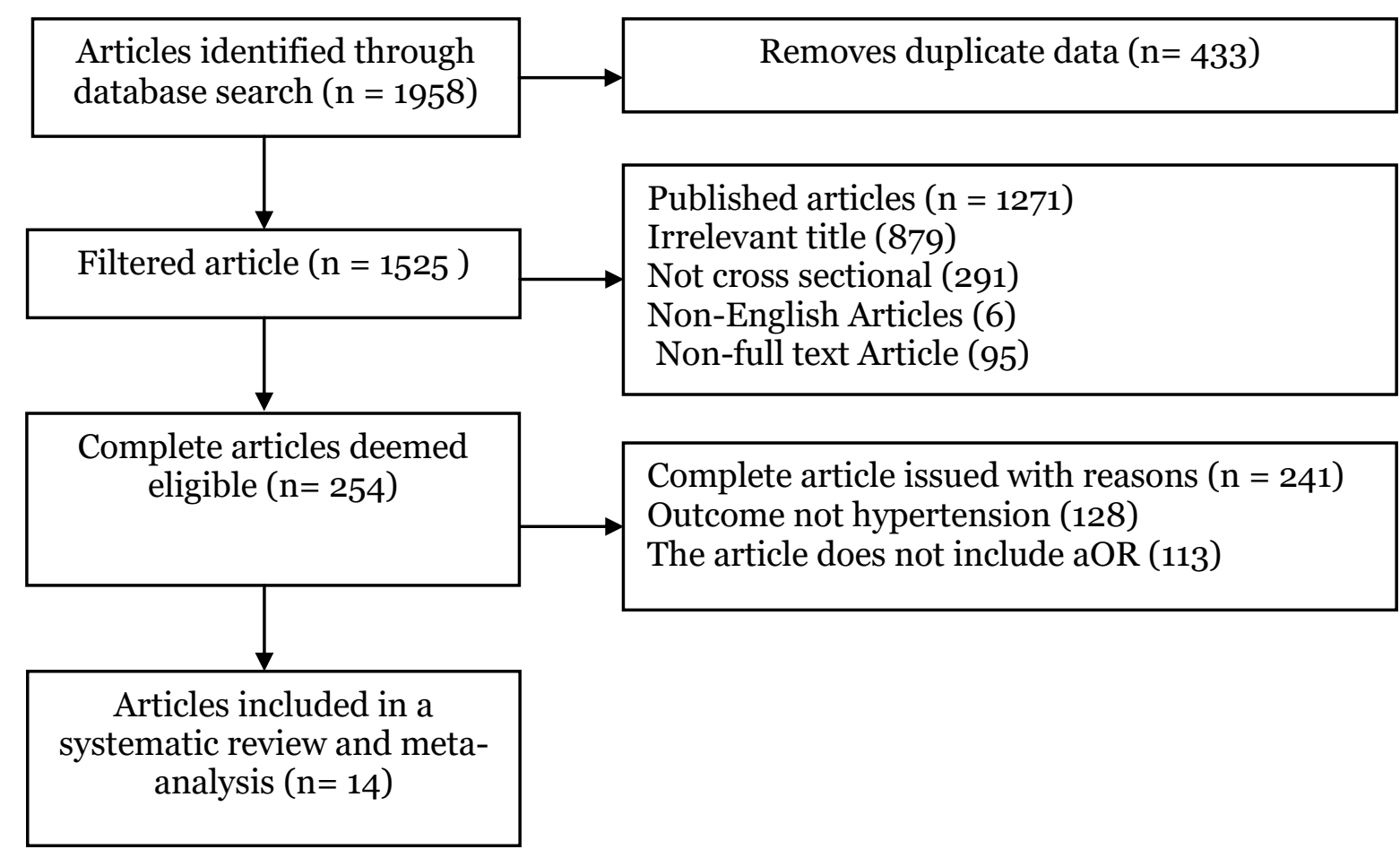

Figure 1. PRISMA diagram flow

The initial search process obtained 1.958 articles, then the process of deleting duplicated articles was carried out, it
Data analysis in this study using RevMan 5.3 and analysis included in this study with fixed effect and random effects analysis.

\section{RESULTS}

The research articles used were searched and selected from several databases, namely PubMed, Science Direct, Springer Link and Go

ogle Scholar. The keywords used for article searches are "Hypertension OR High blood pressure AND Physical activity AND Adolescent", "Hypertension OR High blood pressure AND obesity AND adolescent", "Hypertension OR High blood pressure OR Physical activity OR obesity OR adolescent OR Cross sectional". The process of searching for articles can be seen in the search flow as follows:

Published articles $(\mathrm{n}=1271)$

Irrelevant title (879)

Not cross sectional (291)

Non-English Articles (6)

Non-full text Article (95)

Complete article issued with reasons $(\mathrm{n}=241)$

Outcome not hypertension (128)

The article does not include aOR (113)

obtained 1,525 articles including 254 complete articles and fulfilling the requirements, then a full text article search was 
Berek et al./ The Effects of Physical Activity and Obesity on Hypertension in Adolescents

carried out. Complete articles that were included in the inclusion criteria because of the following reasons:

1. Not using a cross sectional study design

2. Outcome is not hypertension

3. Does not include the aOR value

Research on the effect of physical activity and obesity on the incidence of hypertension in adolescents consists of 14 articles from 4 continents, namely Africa, America, Europe and Asia.

The articles identified and obtained 14 observational articles with cross-sectional study designs were eligible as sources of impact meta-analysis

Physical activity and obesity on the incidence of hypertension in adolescents can be seen in tables 1 and 2 below:

Table 1. The Effect of Physical Activity on the Incidence of Hypertension in Adolescents

\begin{tabular}{llccc}
\hline \multicolumn{1}{c}{ Author (Year) } & Country & Sample & aOR & 95\% CI \\
\hline Omisore et al. (2018) & Nigeria & 1,000 & 1.53 & 0.80 to 2.93 \\
Sarganas et al. (2018) & German & 2,542 & 1.75 & 0.69 to 4.44 \\
Silva et al. (2016) & Brazil & 875 & 2.20 & 1.00 to 4.84 \\
Skhiri et al. (2012) & Tunisia & 2,870 & 4.20 & 1.80 to 9.80 \\
Sudiasih et al. (2019) & Indonesia & 203 & 5.87 & 1.19 to 28.96 \\
Zhang et al. (2019) & Ghana & 1,161 & 1.42 & 1.04 to 1.94 \\
\hline
\end{tabular}

Table 2.The Effect of Obesity on the Incidence of Hypertension in Adolescents

\begin{tabular}{lcccc}
\hline \multicolumn{1}{c}{ Author (Year) } & Country & Sample & aOR & 95\% CI \\
\hline Abolfotouh et al. (2011) & Egypt & 1,500 & 2.18 & 1.38 to 3.44 \\
Benmohammedet al. (2011) & Algeria & 305 & 1.90 & 1.10 to 3.28 \\
Bivigouet al. (2020) & Gabon & 613 & 1.56 & 0.30 to 8.11 \\
Christofaroet al. (2017) & Brazil & 1,231 & 1.04 & 0.63 to 1.72 \\
Dulskieneet al. (2014) & Lithuania & 7,457 & 6.64 & 4.65 to 9.48 \\
Leunget al. (2014) & China & 6,193 & 1.43 & 0.99 to 2.07 \\
Manios et al. (2019) & Greece & 1,444 & 2.61 & 1.88 to 3.62 \\
Omisore et al. (2018) & Nigeria & 1,000 & 12.43 & 4.63 to 33.37 \\
Sarganas et al. (2018) & German & 2,542 & 2.70 & 1.78 to 4.10 \\
Zou et al. (2019) & China & 2,639 & 4.02 & 2.82 to 5.73 \\
\hline
\end{tabular}

a. Forest Plotof Physical Activity and Adolescent Hypertension

Interpretation of the results of the metaanalysis process on the effect of physical activity on the incidence of hypertension in adolescents can be seen through a forest plot:

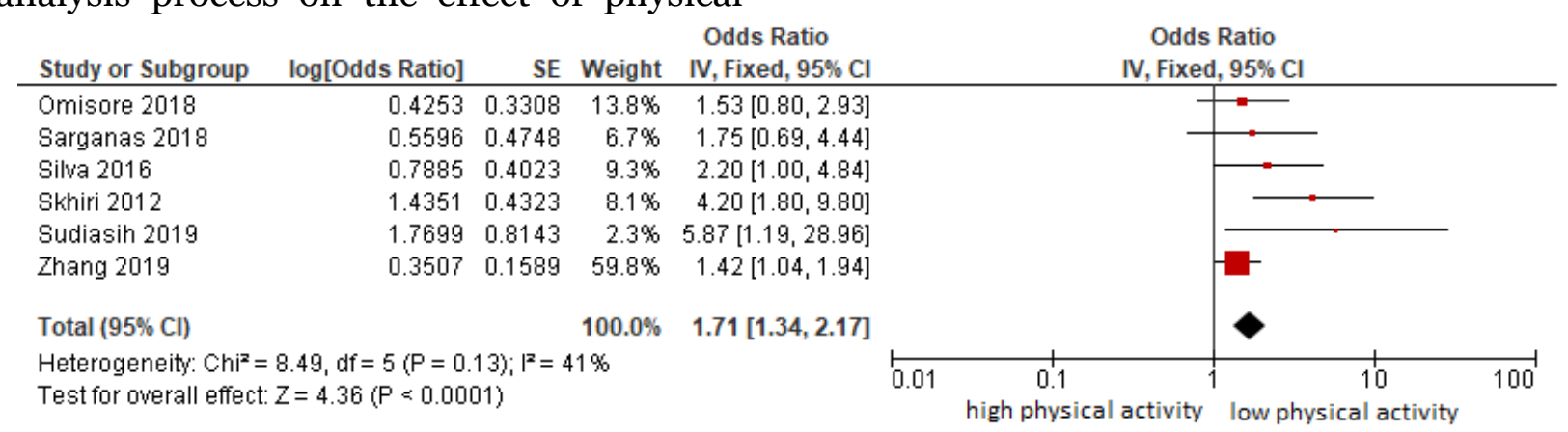

Figure 2. Forest Plot of the Effect of Physical Activity on the Incidence of Hypertension in Adolescents 
Berek et al./ The Effects of Physical Activity and Obesity on Hypertension in Adolescents

Figure 2 shows that adolescents who do low physical activity were 1.71 times increased the risk of hypertension compared to adolescents who do moderate/high physical activity $(\mathrm{aOR}=1.71 ; 95 \% \mathrm{CI}=1.34$ -
2.17) with values $(\mathrm{p}<0.01)$. The heterogeneity of the study data showed I $2=41 \%$, then the data distribution was not heterogeneous (homogeneous) so that it used a fixed effect model.

\section{b. Funnel plot of Physical Activity and Adolescent Hypertension}

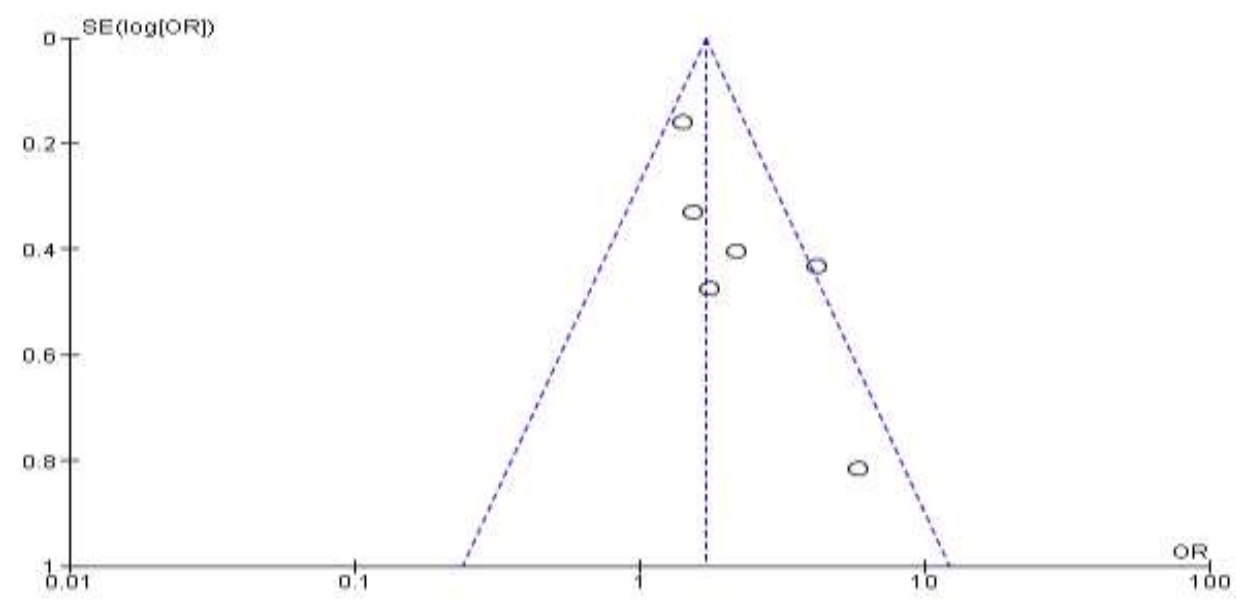

Figure 3. Funnel Plot of the Effect of Physical Activity on the Incidence of Hypertension in Adolescents

Figure 3 showed the publication bias which was characterized by asymmetry between the right and left plots where there are 2 plots on the left and 4 plots on the right. The plots on the left of the graph have a standard error between 0 and 0.2 and all plots on the right have a standard error between 0.4 and 0.8 .

\section{c. Forest Plot of Obesity and Hyper- tension in Adolescents}

Interpretation of the results of the metaanalysis process on the effect of obesity on the incidence of hypertension in adolescents can be seen through a forest plot.

\begin{tabular}{|c|c|c|c|c|c|c|c|c|}
\hline \multirow{2}{*}{$\begin{array}{l}\text { Study or Subgroup } \\
\text { abolfotouh } 2011\end{array}$} & \multirow{2}{*}{$\frac{\log [\text { Odds Ratio] }}{0.7793}$} & \multirow{2}{*}{$\begin{array}{r}\text { SE } \\
0.2333\end{array}$} & \multirow{2}{*}{$\frac{\text { Weight }}{10.9 \%}$} & \multirow{2}{*}{$\begin{array}{c}\text { Odds Ratio } \\
\text { IV, Random, } 95 \% \mathrm{Cl}\end{array}$} & \multicolumn{4}{|c|}{$\begin{array}{c}\text { Odds Ratio } \\
\text { IV, Random, } 95 \% \mathrm{Cl}\end{array}$} \\
\hline & & & & & & & $\longrightarrow$ & \\
\hline Benmohammed 2011 & 0.6419 & 0.2789 & $10.2 \%$ & $1.90[1.10,3.28]$ & & & & \\
\hline Bivigou 2020 & 0.4447 & 0.8412 & $4.0 \%$ & $1.56[0.30,8.11]$ & & & & \\
\hline Christofaro 2017 & 0.0392 & 0.2557 & $10.6 \%$ & $1.04[0.63,1.72]$ & & & - & \\
\hline Dulskiene 2014 & 1.8931 & 0.1818 & $11.5 \%$ & $6.64[4.65,9.48]$ & & & $\rightarrow$ & \\
\hline Leung 2014 & 0.3577 & 0.1876 & $11.4 \%$ & $1.43[0.99,2.07]$ & & & $\leftarrow$ & \\
\hline Manios 2019 & 0.9594 & 0.1674 & $11.6 \%$ & $2.61[1.88,3.62]$ & & & & \\
\hline Omisore 2018 & 2.5201 & 0.5039 & $7.2 \%$ & $12.43[4.63,33.37]$ & & & & \\
\hline Sarganas 2019 & 0.9933 & 0.2126 & $11.1 \%$ & $2.70[1.78,4.10]$ & & & $\rightarrow$ & \\
\hline Zou 2019 & 1.3913 & 0.1809 & $11.5 \%$ & $4.02[2.82,5.73]$ & & & $\rightarrow$ & \\
\hline Total $(95 \% \mathrm{Cl})$ & & & $100.0 \%$ & $2.70[1.81,4.04]$ & & & & \\
\hline \multicolumn{5}{|c|}{$\begin{array}{l}\text { Heterogeneity: } \operatorname{Tau}^{2}=0.33 ; \mathrm{Chi}^{2}=66.79, \mathrm{df}=9(\mathrm{P}<0.00001) ;\left.\right|^{2}=87 \% \\
\text { Test for overall effect: } Z=4.84(P<0.00001)\end{array}$} & 0.01 & $\begin{array}{l}1 \\
0.1 \\
\text { non-obese }\end{array}$ & 1 obese & 100 \\
\hline
\end{tabular}

Figure 4. Forest Plot of the Effect of Obesity on the Incidence of Hypertension in Adolescents

Figure 4 showed that adolescents with obesity were 2.70 times increased risk of hypertension compared to adolescents who were not obese $(\mathrm{aOR}=2.70 ; 95 \% \mathrm{CI}=1.81$ - 
4.04; $\mathrm{p}<0.01)$. The heterogeneity showed $\mathrm{I}^{2}=87 \%$, so the data distribution was heterogeneous (random effect model).

\section{d. Funnel Plot}

Figure 5 showed the publication bias which is characterized by asymmetry between the

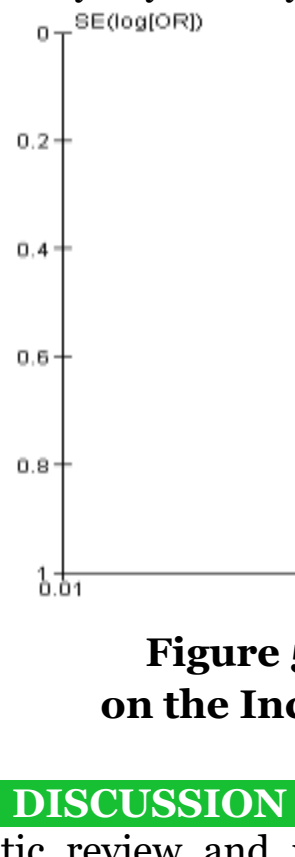

This systematic review and meta-analysis study has the theme of the effect of physical activity and obesity on the incidence of hypertension in adolescents. Study on hypertension in adolescents is considered important because the number of relevant studies that can be accessed is still limited and has data duplication problems (Murti, 2018).

Most studies only report the total percent or crude odd ratio (cOR) so that they cannot control for confounding factors. Confounding factors affect the relationship or effect of exposure to the disease, which may be different from the relationship or exposure that should occur in the population which caused invalid study result (Murti, 2018).

This systematic review and metaanalysis study used studies that controls confounding factors as seen from the inclusion criteria set, namely multivariate right and left plots where there are 7 plots on the left and 3 plots on the right. The plots on the left of the graph have a standard error between $\mathrm{o}$ and 0.8 and all plots on the right have a standard error between 0 and 0.4 .

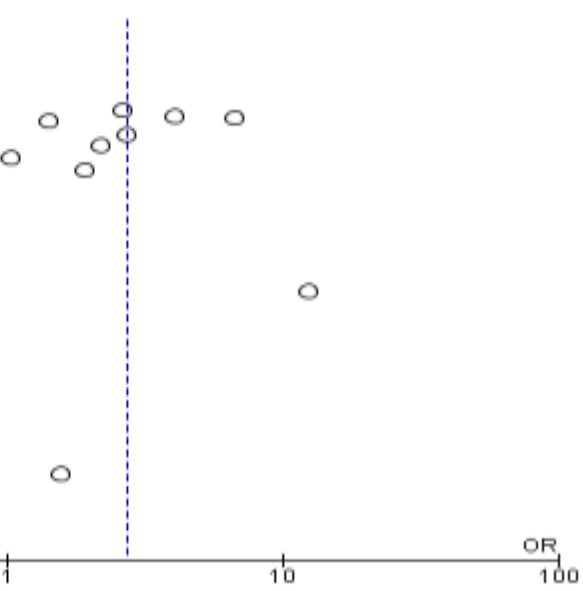


were 1.71 times more likely to have an increased risk of hypertension compared to adolescents who do moderate/high physical activity.

The results of this study are in line with research conducted by Wyszyńska et al, (2017) on adolescents in Poland, which proved that adolescents with low levels of physical activity were 4.40 times higher in increasing the risk of hypertension than adolescents who did high physical activity.

Another study conducted by Barros et al. (2013) in Brazil on 3.764 adolescents showed that $66 \%$ of adolescents reported being physically inactive with a prevalence of high blood pressure of $14.6 \%$. Based on the odds ratio value, inactive adolescents have high blood pressure of 1.24 which mean that adolescents who do not do physical activity are 1.24 times more likely to increase the risk of hypertension.

\section{Obesity and Hypertension}

The results of the forest plot show that obese adolescents were 2.70 times more likely to have hypertension than adolescents who were not obese.

The results of this study are in line with a study conducted in the United States by Ford, Nonnemaker, \& Wirth, (2008) which showed that obese adolescents tend to have high blood pressure than adolescents with normal weight or have higher risk of hypertension by 1.96 times .

Obese adolescents have a higher risk of suffering from cardiovascular diseases including hypertension, where an increase in body mass index will increase the risk of hypertension. Obese adolescents are at risk by 2.5 to 7.6 times greater than adolescents who are not obese (Committee on Adolescent Health Care, 2017).

Stiefel et al (2016) conducted on student athletes in Mississippi, United States showed that obese student athletes were 2.40 times more likely to have blood pressure than student athletes who were not obese and the relationship between obesity and hypertension was statistically significant $(\mathrm{p}<0.001)$.

A limitation of this study is the possible publication bias shown in the funnel plot of the effect of physical activity and hypertension. Language bias occurs because this study only uses research articles published in English and does not use research articles in other languages. Search bias occurs because researchers only use 4 databases (PubMed, Science Direct, Springer Link and Google Scholar) to search for articles so that the researchers do not search other databases.

\section{AUTHOR CONTRIBUTION}

Maria Imakulata Berek, Agus Kristiyanto, and Vitri Widyaningsih, collected and selected the articles, examine critical judgement for each article, did qualitative synthesis, and did quantitative synthesis for meta analysis.

\section{CONFLICT OF INTEREST}

We declare that there is no conflict of interest.

\section{FUNDING AND SPONSORSHIP}

This study did not use any funding and sponsorship due to the secondary data and the databases that could be easily accessed. It also provided open access journals.

\section{ACKNOWLEDGEMIENT}

We thank to authors and online journal databases that provide research related with this study.

\section{REFERENCE}

Abolfotouh MA, Sallam SA, Mohammed MS, Loutfy AA, Hasab AA (2011). Prevalence of elevated blood pressure and association with obesity in Egyptian school adolescents. International Journal of Hypertension. https://doi.- 
Berek et al./ The Effects of Physical Activity and Obesity on Hypertension in Adolescents

org/10.4061/2011/952537.

Aglony M, Acevedo M, Ambrosio G (2009). Hypertension in adolescents. Expert Rev Cardiovasc Ther. 7(12):1595-603. https://doi.org/10.1586/erc.09.150.

Amponsem-Boateng C, Zhang W, Oppong TB, Opolot G, Kyere EKD (2019). A cross-sectional study of risk factors and hypertension among adolescent senior high school students. Diabetes Metab Syndr Obes. 12: 1173-1180. https://doi.org/10.2147/DMSO.S2135 52.

Amra NR, Siregar FA, Mutiara E (2020). Physical activity, obesity, family history, and their associations with hypertension among the elderly in Aceh Singkil, Aceh. J Epidemiol Public Health. 5(1): 45-51. https://doi.org/10.26911/jepublichealth.2020.05.01.0 5 .

Aounallah-Skhiri H, El Ati J, Traissac P, Ben Romdhane H, Eymard-Duvernay S, Delpeuch F, et al. (2012). Blood pressure and associated factors in a North African adolescent population. a national cross-sectional study in Tunisia. BMC Public Health. 12(1): 98. https://doi.org/10.1186/1471-2458-12-98.

Arum YTG (2019). Hipertensi pada penduduk usia produktif (15-64 Tahun) (Hypertension in productive age population (15-64 years old)). J Public Health Res Development. 3(3): 345356. https://doi.org/https://doi.org/10.15294/higeia/v3i3/30235.

Barros MVG, Ritti-Dias RM, Barros SSH, Mota J, Andersen LB (2013). Does self-reported physical activity associate with high blood pressure in adolescents when adiposity is adjusted for?. J Sports Sci. 31(4): 387-395. https://doi.org/10.1080/02640414.2 012.734631.
Batara D, Bodhi W, Kepel BJ (2016). Hubungan obesitas dengan tekanan darah dan aktivitas fisik pada remaja di Kota Bitung (The relationship between obesity and blood pressure and physical activity in adolescents in Bitung City). Jurnal E-Biomedik. 4(1): o-5. https://doi.org/10.35790/ebm.4.1.2016.10842.

Benmohammed K, Nguyen MT, Khensal S, Valensi P, Lezzar A (2011). Arterial hypertension in overweight and obese algerian adolescents: Role of abdominal adiposity. Diabetes and Metabolism. 37(4): 291-297. https://doi.org/10.1016/j.diabet.2010.10.010.

Bivigou EA, Ditombi BM, Nguema OM, Moutongo R, Pongui B, Ekomi BB, et al. (2020). Hypertension and prehypertension: prevalence and predisposing factors in Gabonese Youth and Adolescents. 1-11. https://doi.org/10$.21203 /$ rs.3.rs-24889/v1.

Christofaro DGD, Mesas AE, Dias RM, Fernandes RA, Saraiva BTC, Palma $M R$, et al. (2018). Association between hypertension in adolescents and the health risk factors of their parents: an epidemiological family study. J Am Society Hypertension. 12(3): 182-189. https://doi.org/10.1016/j.jash.2017.12.011.

Committee on Adolescent Health Care (2017). Obesity in Adolescents. The American College of Obstetricians and Gynecologists. Washington DC.

Dulskiene V, Kuciene R, Medzioniene J, Benetis R (2014). Association between obesity and high blood pressure among Lithuanian adolescents: A cross-sectional study. Italian Journal of Pediatrics. 40(5): 1-10. https://doi.org/10.1186/s13052-014-0102-6.

Falkner B (2010). Hypertension in children and adolescents: Epidemiology and 
Berek et al./ The Effects of Physical Activity and Obesity on Hypertension in Adolescents

natural history. Pediatric Nephrology: 25(7): 1219-1224. https://doi.org/10.1007/s00467-009-1200-3.

Flynn JT, Falkner BE (2011). Obesity hypertension in adolescents: Epidemiology, evaluation, and management. Journal of Clinical Hypertension. 13(5): 323-331. https://doi.org/10.1111/j.1751-7176.2011.00452.x.

Ford CA, Nonnemaker JM, Wirth KE (2008). The influence of adolescent body mass index, physical activity, and tobacco use on blood pressure and cholesterol in young adulthood. Journal of Adolescent Health. 43(6): 576-583. https://doi.org/10.1016/j.jadohealth.2008.06.010.

Ikatan Dokter Anak Indonesia (2014). Diagnosis, tata laksana dan pencegahan obesitas pada anak dan remaja (Diagnosis, management and prevention of obesity in children and adolescents).

Kelly RK, Magnussen CG, Sabin MA, Cheung M, Juonala M (2015). Development of hypertension in overweight adolescents: A review. Adolescent Health, Medicine and Therapeutics. 6: 171-187. https://doi.org/10.2147/AHMT.S55837.

Kemenkes RI (2019). Hipertensi si pembunuh senyap (Hypertension the silent killer). Kementrian Kesehatan RI, 1-5. Retrieved from https://pusdatin.kemkes.go.id/resources/downlo ad/pusdatin/infodatin/infodatinhipertensi-si-pembunuh-senyap.pdf

Lembaga Demografi FEB UI (2017). Brief notes: Prioritaskan kesehatan reproduksi remaja untuk menikmati bonus demografi (Brief notes: Prioritize adolescent reproductive health to enjoy the demographic bonus). 1-6. Retrieved from http://ldfebui.org/wp-content/uploads/2017/o8/BN-06-2017.- pdf.

Leung LCK, Sung RYT, So HK, Wong SN, Lee KW, Lee KP, et al. (2011). Prevalence and risk factors for hypertension in Hong Kong Chinese adolescents: Waist circumference predicts hypertension, exercise decreases risk. Archives of Disease in Childhood. 96(9): 804-809. https://doi.org/10.1136/adc.2010.202770.

Manios Y, Karatzi K, Moschonis G, Ioannou G, Androutsos O, Lionis C, Chrousos $G$ (2019). Lifestyle, anthropometric, socio-demographic and perinatal correlates of early adolescence hypertension: The Healthy Growth Study. Nutrition, Metabolism and Cardiovascular Diseases. 29(2): 159-169. https://doi.org/10.1016/j.numecd.2018.10.007 .

Murti B (2016). Prinsip dan Metode Riset Epidemiologi (Epidemiological Research Principles and Methods). Karanganyar: Bintang Fajar Offset.

Omisore AG, Omisore B, Abioye-Kuteyi EA, Bello IS, Olowookere SA (2018). Inschool adolescents' weight status and blood pressure profile in South-western Nigeria: urban-rural comparison. BMC Obes. 5: 2. https://doi.org/10.1186/s406o8-018-0179-3.

Pusdatin Kemenkes RI (2017). Infodatin reproduksi remaja: Situasi kesehatan reproduksi remaja. Retrieved from https://www.kemkes.go.id/download. php?file=download/pusdatin/infodati $\mathrm{n} /$ infodatin reproduksi remaja-ed.pdf Sarganas G, Schaffrath RA, Niessner C, Woll A, Neuhauser HK (2018). Tracking of blood pressure in children and adolescents in Germany in the context of risk factors for hypertension. International Journal of Hypertension. 2018(1). https://doi.org/10.1155/2018/8429891. 
Silva DAS, Tremblay M, Pelegrini A, Silva RJDS, De Oliveira ACC, Petroski EL (2016). Association between aerobic fitness and high blood pressure in adolescents in Brazil: Evidence for criterion-referenced cut-points. Pediatric Exercise Science. 28(2): 312320. https://doi.org/10.1123/pes.2015-0172.

Stiefel EC, Field L, Replogle W, McIntyre L, Igboechi O, Savoie FH (2016). The prevalence of obesity and elevated blood pressure in adolescent student athletes from the State of Mississippi. Orthopaedic Journal of Sports Medicine, 4(2): 1-9. https://doi.org/10.1177/2325967116629368.

Sudiasih N, Wirawan D, Sidiartha I (2019). Association between physical activity, fiber and salt intake with hypertension in adolescents with obesity. Public Health and Preventive Medicine Archive 7(1): 54-59. DOI:10.15562/phpma.v7i1.195.

WHO (2013). A global brief on hypertension WHO 2013. In Who. Retrieved from www.who.int.

Wyszyńska J, Podgórska-Bednarz J, Dereń
K, Mazur A (2017). The relationship between physical activity and screen time with the risk of hypertension in children and adolescents with intellectual disability. Biomed Res Int. 2017: 1940602. https://doi.org/10.1155/2017/1940602.

Yusrizal M, Indarto D, Akhyar M (2016). Risk of hypertension in adolescents with over nutritional status in Pangkalpinang, Indonesia. $\mathrm{J}$ Epidemiol Public Health. 1(1): 27-36. https://doi.org/10.26911/jepublicheal th.2016.01.01.04.

Zou Y, Xia N, Zou Y, Chen Z, Wen Y (2019). Smartphone addiction may be associated with adolescent hypertension: A cross-sectional study among junior school students in China. BMC Pediatrics. 19(1): 1-8. https://doi.org/10.1186/s12887-019-1699-9. 